\title{
Gender at the Margins of Contemporary Constitutional Citizenship
}

\section{Rogers M. Smith}

One revealing fact about the subject of this essay is that, if we wish to focus on recent Supreme Court decisions that specifically address the relationship of gender to constitutional citizenship, there are very few cases to consider. If we leave aside related but distinguishable issues involving abortion rights and sexual orientation, the most discussed constitutional cases involving discriminatory treatment of women in the last decade are probably United States v. Virginia (518 U.S. 515 [1996]) and United States v. Morrison (529 U.S. 598 [2000], followed by a less famous but in some respects more pertinent case, Tuan Anh Nguyen v. Immigration and Naturalization Service (533 U.S. 53 [2001]). Feminist legal scholars have also been struck by the late Chief Justice William Rehnquist's surprisingly strong defense of the Family and Medical Leave Act of 1993 against an $11^{\text {th }}$ Amendment challenge in Nevada Department of Human Resources v. Hibbs (538 U.S. 721 [2003]).

In all these cases, questions of gender and constitutional citizenship were in important respects marginal issues, though in different ways in each case. In U.S. v.

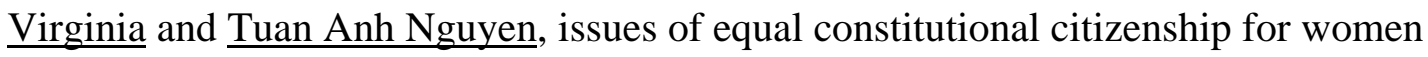
were explicitly at the center of the matters the justices considered. But the contexts of the cases_-a woman seeking admission to an all-male public military college, a man claiming citizenship who was born abroad to an unmarried citizen father and a noncitizen mother-were ones well outside the experiences of most Americans. Conversely, 


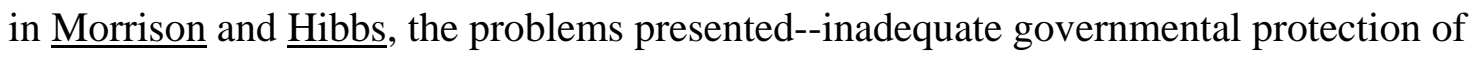
women against violence, unequal provision of paid leave for men and women under the Family and Medical Leave Act of 1993 — were crucial ones for the well-being of women. But none of the justices who wrote opinions gave any substantial, explicit attention to issues of gender and equal constitutional citizenship. Beyond these decisions, such questions are even less detectable in most recent judicial constitutional discussions.

This dramatic marginality of the topic of gender and equal citizenship is what I wish to explore here. Perhaps alarmingly, my thesis is that it is in some ways appropriate for gender and constitutional citizenship to be a marginal theme in Supreme Court decision-making today, because the most important tasks in restructuring American institutions to remove barriers to meaningfully equal citizenship for women and men now go far beyond the capacities and the legitimate authority of the judiciary when engaged in constitutional interpretation. But though the role of the courts in this area may appropriately be marginal, it should not be trivial. The courts do have a constitutional duty to pursue gender equality and civic equality to the very margins of their institutional competence. Even when it would be wrong for them to devise and mandate sweeping remedies, they should scrutinize more closely public policies and institutional arrangements that foster conditions in which women do not on balance have equal practical opportunities to be politically active citizens. Their rulings can then help highlight the most important tasks of civic restructuring that confront the rest of us. I believe too many recent decisions are instead focusing on the wrong issues in the wrong ways, failing to call attention to what, from the standpoint of constitutional citizenship, still needs to be done to realize gender equality in life as well as in law. 
I. Recent Constitutional Decisions. Modern gender equal protection doctrine arose as part of the manifold efforts to combat diverse forms of second-class citizenship inspired by the modern civil rights movement. Ruth Bader Ginsburg was of course a major, perhaps the major, leader of struggles to overcome denials of equal citizenship to women via litigation, and she made those themes rhetorically central to her opinion for the Court in U.S. v. Virginia (Strum 2003, 335). The case provided a suitable occasion for addressing citizenship because it considered whether women could be constitutionally excluded from the Virginia Military Institute, a public institution that takes as its "distinctive mission" the training of "citizen-soldiers" who will be leaders in the military and civilian life (520). Ginsburg ruled that VMI's gender exclusion was not substantially related to this goal, as some women could benefit from the "adversative" education VMI provided. False judgments to the contrary, she wrote, had "attended, and impeded, women's progress toward full citizenship stature throughout our Nation's history” (544n12). But today, she observed, women "count as citizens in our American democracy equal in stature to men” (545). Therefore "the Court has repeatedly recognized that neither federal nor state government acts compatibly with the equal protection principle when a law or official policy denies to women, simply because they are women, full citizenship stature- equal opportunity to aspire, achieve, participate in and contribute to society based on their individual talents and capacities” (532).

Ginsburg's reasoning put the decision squarely in the line of civil rights cases and statutes that have over time invalidated a great variety of institutional exclusions that limited material opportunities and also symbolized inferior civic status (Strum 2003, 337340). The civic republican traditions that have played so great a role in defining the 
meaning of citizenship in America have often presented the full citizen as a citizensoldier, someone who has been willing and able to make the ultimate sacrifice for the common good. Hence military service has long been a pathway to citizenship—but through most of U.S. history, not for women (Kerber 1998, 236-252). Ginsburg was on solid ground when she saw VMI's denial of access to preparation to become a citizensoldier and civic leader as a denial of an opportunity to be recognized as a full and equal citizen, as defined by certain influential American conceptions of citizenship. It might seem, then, that there is nothing marginal about the issues of gender and constitutional citizenship in this case.

The reality is, however, that by the time of the VMI decision, all the U.S. military academies that actually feed directly into the military services (as VMI largely does not) had come to admit women (522, 544n13). After the Citadel in South Carolina changed its policy, VMI had been left as the only remaining public military college that was exclusively male, and it was "one of the last remaining male bastions" among public and, indeed, private institutions generally (Strum 2003, 340). Thought it is an important institution in Virginia and the Court was surely right to protect female opportunities in the case, the decision was essentially the final nail in a crowded coffin for male-only public colleges. However we assess its symbolic value, a point to which I will return, it had only a minor impact on the material circumstances and prospects of most American women.

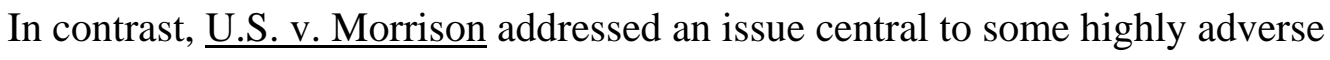
and all too material circumstances facing American women today. It concerned whether or not Congress had the constitutional power to enact §40302 of the Violence Against 
Women Act of 1994, which sought to create a "Federal civil rights cause of action for victims of crimes of violence motivated by gender” (42 U.S.C. §13981b). They were to be empowered to sue for "compensatory and punitive damages, injunctive and declaratory relief, and such other relief as a court may deem appropriate.” Like major portions of the 1964 Civil Rights Act, Congress based the Violence Against Women Act on congressional power to regulate activities that substantially affect interstate commerce, and it also invoked its authority to enforce equal protection violations under $\S 5$ of the Fourteenth Amendment. When seen in their broader political and historical contexts, both the 1964 Civil Rights Act and the Violence Against Women Act clearly sought to make the civic status of those they protected more secure, as well as, and in part through, assisting their physical and economic well-being (Davis 2003, 64-65). And at the height of the civil rights movement, the Court had little trouble upholding the 1964 Civil Rights Act.

But in 2000, Chief Justice William Rehnquist writing for the Court concluded that to read congressional commerce powers broadly enough to encompass non-economic crimes against women along with economic activities would be to turn it into a national police power, something the Constitution did not provide (617-618). He also held that, even though "a voluminous congressional record" showed "pervasive bias in various state justice systems against victims of gender-motivated violence," this pattern did not permit Congress to create a new federal cause of civil actions against the individual perpetrators of gender violence across the nation (619-620, 625-26). The federal government did have power to act against officials in particular states who were guilty of failing to protect victims of such violence-but §40302 of the Violence Against Women 
Act was not addressed to such officials. Consequently, the Supreme Court voided that portion of the act, taking away a major instrument through which women could gain redress for economic and personal injuries that states were failing to remedy.

Substantively important as this decision was, it turned on arguments about federalism and the scope of congressional powers. Gender and constitutional citizenship receive no attention in any of the opinions in the case. Neither the government's brief nor that of the original petitioner, Christy Brzonkala, so much as mentioned citizenship (Waxman et al. 1999; Davis et al. 1999). Of the 22 other briefs in the case, only the amicus brief of the law's original sponsor, Senator Joseph Biden, expressed explicit concern about combating women’s "second-class citizenship.” It did so only via a short unelaborated quotation from testimony given by Helen R. Neuborne, formerly Deputy Director of the NOW Legal Defense and Education Fund, during Senate hearings on the bill (Biden 1999, 13).

Perhaps in consequence, the Court's language and reasoning reflected "resistance to the 'public' nature of the problem, to the link between violence and liberty, violence and autonomy, violence and women’s full participation and citizenship,” as Elizabeth Schneider has argued (Schneider 2003, 214). Despite their strengths, neither of the dissents by Justices David Souter and Stephen Breyer gave any attention to the ways the Act sought to combat behavior that had long contributed to women's subordination in their civic roles as well as in many other regards. This decision, then, is perhaps the most consequential, and adversely consequential, of recent Supreme Court cases concerning women; but it is one where gender and citizenship are at the margins of analysis and, 
indeed, must be interpolated by readers if those themes are to be part of the case discussion at all.

In the third pertinent recent Supreme Court decision, Nguyen v. INS, citizenship and gender are certainly front and center, both in the majority opinion by Justice Anthony Kennedy and in Justice Sandra Day O’Connor's blistering dissent. The case arose because while working for a corporation in Saigon, a U.S. citizen, Joseph Boulais, fathered a child, Tuan Anh Nguyen, with a Vietnamese women whom he did not marry. When the boy was six, Boulais brought him to Texas and raised him to adulthood. But at age 22, Nguyen was convicted of sexual assault on a minor, and the INS initiated deportation proceedings. Nguyen subsequently claimed that he was a U.S. citizen, exempt from deportation. He acknowledged that his father had not done all that federal statutes require to obtain citizenship for children situated like himself. But he and his father challenged the constitutionality of 8 U.S.C. §1409, which sets out the conditions under which a person born out of wedlock to one citizen and one non-citizen parent can gain American citizenship.

Specifically, they raised a gender equal protection challenge to the differential treatment of women and men under $\S 1409$. When the father is the citizen parent, §1409(a) requires that the blood relationship be established by "clear and convincing evidence;” and while the child is under 18, the relationship must be legitimated under the law of the child's place of residence, or the father must acknowledge paternity in writing under oath, or the paternity must be established by adjudication of a competent court. In contrast, if the mother is the citizen parent, §1409(c) provides that the child is 
automatically a U.S. citizen, so long as the mother has previously been physically present in the U.S. or one of its possessions for a continuous year (56-60).

Clearly these provisions treat male and female citizens differently. The Court found, however, that this differential treatment met its doctrinal demand that such distinctions be "substantially related" to "important governmental interests." The two governmental interests discerned by Justice Kennedy were first, "assuring that a biological parent-child relationship exists” (62), presumably so that birthright citizenship might not be inaccurately awarded. In this regard, Kennedy argued, fathers and mothers are "not similarly situated": a birth certificate signed by witnesses to the physical birth confirms who a child's mother is, whereas the putative father might not even be present or, if present, might still not actually be the biological father (62-63). Therefore, asking more for proof of paternity than maternity in such cases seemed reasonable.

Kennedy defined the second governmental interest as ensuring "that the child and the citizen parent have some demonstrated opportunity or potential to develop not just a relationship that is recognized, as a formal matter, by the law, but one that consists of the real, everyday ties that provide a connection between child and citizen parent and, in turn, the United States” (64-65). For the mother, that opportunity could be presumed to come at birth. For the father, who again might be absent from the birth, some further demonstration that such an opportunity existed at some time could legitimately be required. In Kennedy's view, the government could rightly treat assurances that there was once an opportunity for a real continuing relationship as a substantial contribution to the important goal of having citizens feel an attachment to their country. 
Justice O'Connor's dissent contended that it was not enough to show that men and women were not similarly situated in regard to the birth process. To uphold the gender discrimination, the government had to show that the discrimination itself substantially advanced important governmental interests that could not be so readily achieved through gender-neutral policies (75). She thought the government had failed to meet this burden. Given the unreliability of documentation, it could have required all citizen parents, male or female, to prove their parental status via DNA tests. Or it could have extended citizenship to the children of all citizen parents whose parental status and presence at the birth were attested to on a valid birth certificate—as is often true of fathers and not always true of mothers (81-82). And in regard to the state interest in demanding proof of merely the "opportunity" for an actual relationship, an interest that Justice O’Connor regarded as Justice Kennedy's invention, she noted that the government might more sensibly require parents of either sex to show that they had had some real contact with the child over a period of time $(84,89)$. She insisted that neither the government nor the majority of the Court had shown why the discriminatory provisions furthered the stated governmental interests better than gender-neutral approaches. O’Connor contended that the provisions instead were "paradigmatic of a historic regime that left women with responsibility, and freed men from responsibility, for nonmarital children.” It reflected and thereby reinforced stereotypes "that mothers must care for these children and fathers may ignore them” (92). By structuring the capacity to transmit citizenship in these gendered terms, the statute built into the law the expectation that mothers would normally be responsible for their children and fathers frequently would not, especially in the cases of children born outside of marriage--an expectation 
likely to perpetuate arrangements that disproportionately burdened women and thereby limited their opportunities for equal citizenship.

Here, then, is a case in which issues of gender and constitutional citizenship are at the very heart of what is in question. Yet central as our topic is to this decision, the case itself involves circumstances that are rare. Times have changed in many ways, but it remains true that, in relation to the U.S. population, only a tiny number of people have been born out of wedlock to citizen fathers overseas. Though the U.S. Census lacks reliable data on this topic, the advocacy group American Citizens Abroad estimates that in the 1990s, roughly 45,000 children a year were born overseas to a U.S. citizen parent, and only $10 \%$ of those, or 4,500 a year, fell into categories in which, like Tuan Anh Nguyen, they did not automatically receive citizenship at birth. An unknown subset of that 4,500 were children born out of wedlock to an American father (Sundberg 2007). Whatever the precise numbers, in a nation of over 300 million people, these births undeniably represent a demographically minor phenomenon. Though the denial of citizenship to those affected is a significant concern, most American women and most forms of gender inequality have not been affected by this ruling one way or another. Add in the fact that, like so many modern gender equal protection cases, the case involves a challenge by males against a statutory discrimination that they reasonably perceive as working against them, however much it may also perpetuate constraining stereotypes about women, and again this is a decision that seems marginal in its implications for achieving equal constitutional citizenship for women.

Nevada Department of Human Resources v. Hibbs is in many respects a

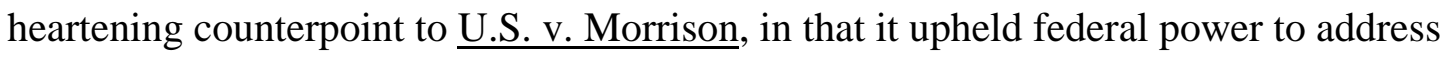


economic conditions vital to the practical realization of gender equality. But though Chief Justice Rehnquist, in his last opinion addressing sex discrimination, wrote with far more sensitivity to state failures to protect women's rights than he had just three years before, he still did not explicitly connect the issues at hand with constitutional citizenship. That topic receives only one scant mention in any of the opinions of the case, in Justice Kennedy’s dissent.

William Hibbs had taken leave from the Nevada Department of Human Resource's Welfare Division to care for his wife after she had suffered neck injuries in an automobile accident. The Department eventually contended that he had exhausted his leave under the Family and Medical Leave Act (FMLA) and had to return to work or be terminated. Disagreeing, Hibbs sued the agency for violating the FMLA, arguing that, exercising its powers under $\S 5$ of the $14^{\text {th }}$ Amendment, Congress had overridden the state's $11^{\text {th }}$ Amendment immunity against suits brought by its own citizens. The Court had previously ruled Congress could abrogate the $11^{\text {th }}$ Amendment (Fitzpatrick v. Blitzer, 427 U.S. 445, 456 [1976]) so long as it was exercising legitimate §5 powers (though it could not do so an exercise of its authority over interstate commerce).

Chief Justice Rehnquist held that the clear congressional intent to abrogate the $11^{\text {th }}$ Amendment via the FMLA was valid, because $§ 5$ powers include authority to pass "prophylactic" laws deterring unconstitutional conduct. He believed Congress had found solid evidence that prior to the FMLA, states had continued "to rely on invalid gender stereotypes in the employment context, specifically in the administration of leave benefits." States often adopted policies that permitted women, but not men, to have more leave than was medically required, out of the belief that care for children, elderly parents, 
or ailing relatives was fundamentally “women’s work” (728-29). The Act therefore gave all state citizens the right to sue their states if they believed that its agencies were perpetuating such unconstitutional discrimination.

Justice Kennedy, joined in dissent by Justices Scalia and Thomas, found the evidence that states discriminated in the provision of family leave insufficient to "support the charge that a State has engaged in a practice designed to deny its citizens the equal protection of the laws.” It is likely that Kennedy was not in fact particularly focused on the equal protection implications for citizens per se, and that he could as easily have written that states had not sought to deny “persons” equal protection. In any case, other

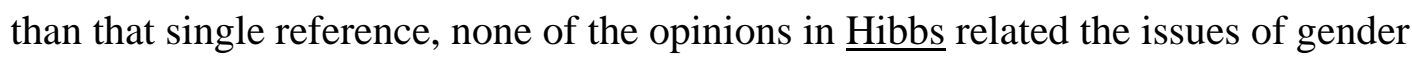
equality to constitutional citizenship, apart from the substantively unrelated question of when state citizens can constitutionally sue their own state governments.

In a perceptive analysis of Chief Justice Rehnquist’s “new approach” to pregnancy discrimination in the $\underline{\text { Hibbs }}$ case, Reva Siegel repeatedly invokes "the equal citizenship principle” to clarify his holding (Siegel 2006, 1881, 1886, 1888, 1897). She does not define that principle, but she does stress that the "practices of sexual differentiation" understood to violate it "have evolved over time” and that Rehnquist came to recognize this historical shift $(1888,1897)$. In particular, he saw that policies that presumed that the father had primary responsibility to provide outside income while women were the "center of home and family life” could operate as unjust "artificial constraints” on women's opportunities. Siegel's invocation of the equal citizenship principle implies, reasonably enough, that those opportunities include arrangements that allow women to be equally active, politically effective citizens. And it is also reasonable 
to suggest that such considerations might have contributed to Rehnquist’s concern with invidious gender discrimination in $\underline{\text { Hibbs. }}$.

Nonetheless, his explicit argument was simply that the FMLA “is narrowly targeted at the fault line between work and family-precisely where sex-based overgeneralization has been and remains strongest” (735). For him constitutional gender equality, which the $14^{\text {th }}$ Amendment extends to persons, not citizens, was most challenged by the ways governments have structured familial and workplace roles and responsibilities. If these structures were connected to equal constitutional citizenship in his analysis, those connections remained unstated, left at the level of implication—which leaves the topic of gender and constitutional citizenship again at the margins of discussion in this case.

II. Why Marginality? Why is it that the current Supreme Court either deals with gender and constitutional citizenship in circumstances that seem marginal to the main structures of inequality that still stand in the way of civic equality for women, or else when it does deal with such circumstances, as in the case of violence against women and the structuring of familial and workplace rights and duties, gender and citizenship become marginal to the constitutional analyses the justices conduct? My answer here is not very original, because a host of feminist scholars, including Catherine MacKinnon, Martha Fineman, Iris Young and many others, have ably identified the pertinent considerations over several decades, though their analyses of course vary in important ways. As I see it, the difficulties of the approach to gender equal protection adopted by most justices of the Supreme Court are well exemplified in Justice O’Connor's generally compelling dissent in Nguyen v. INS. There she rehearses how, in light of America's 
"long and unfortunate history of sex discrimination," the Court has come to treat "the avoidance of gratuitous sex-based distinctions" as the "hallmark of equal protection," so that such distinctions merit heightened scrutiny $(74,82)$. In contrast, "facially neutral laws that have a disparate impact are a different animal," one that “does not trigger heightened scrutiny” (82-83). Even those justices most concerned to achieve equality of constitutional citizenship for women and men become vigilant chiefly when laws explicitly distinguish between the sexes, not when formally neutral laws affect women and men very differently.

But in so doing, they are probably focusing their attention and ours in the wrong places if we are to confront the major obstacles to gender civic equality today. In the wake of the egalitarian reforms of the civil rights era, laws that explicitly disadvantage women on the basis of their sex alone, or even laws that explicitly treat women and men differently, are far less common than once they were. As many scholars have recognized, the greatest gendered barriers to civic equality now derive from the fact that working women continue to do almost twice the amount of care for children and family dependents per day as working men, as well as almost $50 \%$ more of the shopping and more than twice as much housework, while spending somewhat less time in paid employment positions (Bureau of Labor Statistics 2006). These conditions create barriers to economic advancement that are compounded by greater risks of sexual harassment in the workplace. Both burdens are reinforced by criminal justice and social policies that often fail to punish domestic and workplace abusers and that often impose heavy child care and wage labor requirements on poor women, frequently single mothers (Hirschmann 2003, 102-169). Many of those laws and institutions are, however, facially 
gender neutral; and some of those that are not are protective of women in ways that express not demeaning stereotypes but recognition of real problems. It is the inadequate and inappropriate enforcement of some laws and the all too predictable impact of the practices that prevail under many policies that do the damage.

And the damage is great. Though women have far greater formal opportunities than in the past and many are achieving great economic and political success, overall public policies and social practices still structure the lives of most women so that they carry disproportionate responsibilities for family and household care and face greater difficulties acquiring economic resources—as the authors of the Family and Medical Leave Act recognized. Schneider, Siegel and others are right to stress explicitly, even if Rehnquist did not, the civic and political consequences of these disproportionate everyday burdens. In practice they mean that overall, women do not really have meaningfully equal chances to gain and exercise political influence, or to have "full citizenship stature” as Justice Ginsburg appropriately defined it in $\underline{\text { U.S. v. Virginia_一as }}$ "equal opportunity to aspire, achieve, participate in and contribute to society based on their individual talents and capacities.”

As writers like Martha Fineman (2003, 238-39) and Joan Tronto (2005, 138-43) have argued, it seems necessary today to recognize that many forms of care-giving are shared, collective, human responsibilities that should be borne equally by women and men through whatever combination of public and private agencies seems most equitable, efficacious, and politically obtainable. Based upon such recognition, we need to go far beyond the willingness to extend men as well women leave time for domestic care as provided by the FMLA, important as that is. We need to engage in a massive 
restructuring of how child care, housework, and marketplace employment are practiced and given social support, even as we also better enforce protections against gender discrimination and abuse at home, in workplaces, and in public arena.

But gaining support for such measures from a critical mass of men is an extraordinarily daunting task. I have previously argued that this so both because current arrangements spare men a good deal of domestic work that is inherently unappealing and, even more, because many men receive a "psychological wage" from perceiving themselves as the dominant gender. This psychological affirmation may well be more fundamental to their identities than the "wage" that W. E. B. Dubois argued many whites receive from seeing themselves as the superior race (Smith 2001, 190-94). Most men are not only content with, they are profoundly invested in public and private practices that permit them to continue to sustain most of the advantages traditional gender roles have provided them, even under a regime that largely embodies formal legal equality. (If this generalization seems harsh, let me note that I do not exempt myself from it).

Given these contemporary conditions, when courts employ doctrines that prompt them to focus on cases that present something like old-fashioned overt invidious gender discrimination, they inevitably end up giving lots of attention to controversies involving circumstances that are now fairly rare or marginal, like those of VMI and Tuan Anh Nguyen. When, in contrast, the courts confront institutional arrangements that do not explicitly treat women worse or even differently, such as the assignment of police powers under American federalism and doctrines defining the boundaries of what constitutes interstate commerce, their refusal to pay attention to impacts often means that they do not see equal protection analyses of gender and constitutional citizenship as relevant to their 
decision-making. That can remain true even when courts recognize, as Chief Justice Rehnquist did in U.S. v. Morrison, that there is a good deal of empirical evidence showing that workplace harassment and other forms of violence against women incapacitate women in many ways and go uncorrected in many states. The judiciary's doctrinal commitment to giving minimal scrutiny to the differential impact of facially neutral laws still permits them to avoid considering whether these practices mean that in actuality, women do not have the equal opportunities that constitute the heart of constitutional citizenship. Even in Hibbs, Rehnquist really only permitted a state citizen to sue to insure that he was being granted the facially neutral leave time provided for the Act. There was no clear indication that state laws might be constitutionally deficient if, despite their gender neutrality, they still worked in practice to perpetuate the disproportionate burdens for domestic care that women bear, in ways that often constrain women's civic engagement. Prevailing modes of equal protection analysis thus often end up marginalizing the topic of citizenship and gender precisely when courts consider many of the circumstances that today stand as the greatest barriers to concretely equal civic status for women and men.

III. Setting the Margins Straight. If these points are even roughly right, they have implications for the sorts of processes and institutions that can be expected to contribute to meaningful change. In some ways I would like to be able to say that they point to a reorienting of judicial doctrine in which the courts would adopt strict scrutiny for laws that have differential impacts on the basic opportunities that American institutions and practices provide to women and men. Yet I doubt that is the right answer. Although restructuring care for children, the elderly, and other dependents, changing the structure, 
expectations, and reward systems of private as well as public workplaces, and transforming customary divisions of labors within households all seem necessary to achieve more meaningfully equal citizenship, it is far from clear that courts should make mandating such transformations central to their equal protection decision-making. It is not clear because courts do not obviously possess the expertise or the authority to devise new institutional arrangements that would really work better. They also do not command the political support to insure acceptance for the innovations they may prefer (Sunstein 1999). Above all other examples, the bitter failures of fifty years of judicial efforts to integrate public schools stand as chastening warnings to all who presume that, because existing arrangements fail to realize core constitutional values, it is therefore incumbent upon the judiciary to create arrangements that will do so more fully.

At this point I risk coming to a not very appealing conclusion: precisely because the chief barriers to gender civic equality are deeply entrenched public and private institutional arrangements that have grossly disparate impacts, burdening women in ways that still make it harder for women than for men to be politically and economically powerful citizens, it is likely that gender and constitutional citizenship must remain marginal in modern constitutional jurisprudence. The courts cannot do a great deal to change the things that need to be changed if we are to realize constitutional goals more fully. Though I think there is a good deal of truth in that doleful conclusion, I also believe that what the courts are doing now is not the best that they can do. And I think that the quest to overcome gender obstacles in realizing constitutional citizenship for all is a goal that can usefully be made part of political discourses outside the courts, throughout all of American political life. 
First on courts: I have already suggested that if judges seek to assess the differential gender impacts of every law, they may soon fall into speculative inquiries well beyond their competencies, and in any case they are unlikely to command the political support required to implement whatever changes they may order. The difficulties of such inquiries do not mean, however, that courts should abstain from them entirely. They call rather for courts to seek to learn from the parties involved in litigation whether there are impacts of laws and policies that are largely agreed upon; and when judges find such agreements, they should feel entitled to act in appropriate ways, especially through support for government actions working in the right directions. In the case of the Violence Against Women Act, for example, greater weight should have been given to the acknowledged fact that America's structure of federalism means that many women in many states are not adequately protected against many forms of gendermotivated violence. In light of those facts, which all recognized to be part of longstanding patterns of subordination of women and which therefore perpetuated major obstacles to civic equality as well as to personal safety for women, the Court should not have had difficulty in finding that the Act was justified by Congress's authority under the Fourteenth Amendment to insure that all states provide to all persons the equal protection of the laws. In this regard, Chief Justice Rehnquist’s subsequent Hibbs decision, relying on evidence of state discrimination in leave policies to support the $14^{\text {th }}$ Amendment authority of Congress to pass prophylactic legislation, is indeed exemplary. Yet even that refreshing opinion would have been strengthened if the Chief Justice had explicitly connected the structures of workplace and domestic inequality in question to principles of equal citizenship, as Siegel did in analyzing his decision. More generally, judicial 
attention to differential impacts on constitutional citizenship should not just be seen as appropriate. It should be mandatory when judges assess whether other government officials, legislators and executive officers, have had good and constitutional reasons for adopting the measures that are challenged before the courts.

I do think that the limitations of judicial competence, authority and power make it advisable to exercise caution in imposing sweeping remedies based on the courts' own assessments of differential impacts. With Robert A. Burt (1992), I believe the courts often operate most appropriately and constructively when they decide cases in ways that highlight the constitutional failings of current arrangements, without seeking themselves to mandate all that must be done to reform those arrangements. I would therefore have courts extend something like the intermediate scrutiny they apply to explicit gender classifications to laws that operate in ways that generate differential gender outcomes, with the understanding that intermediate scrutiny does not mean that laws must be frequently invalidated and existing institutional arrangements overturned on a wholesale basis. But if, for example, laws and public policies foster work requirements, including the number and scheduling of hours worked, that mean that persons who are doing extensive child care are less likely to retain employment or be promoted, and if in practice these stand as obstacles to equal citizenship for women, then judicial review of those laws and public policies should call attention to those consequences. Though grounds may be sought, in the fashion Louis Brandeis and Alexander Bickel advocated, for deciding cases narrowly and avoiding radical remedial orders, the courts can usefully highlight the ways existing arrangements appear to be working against constitutional goals and values. Such decisions can prompt other political actors-legislators, 
executive agency officials, advocacy groups, policy analysts, and yes, citizens—-to seek to define and win support for more desirable alternate arrangements.

To be sure, as the Hibbs decision suggests, much useful work along these lines can be done in the process of interpreting statutes governing employment, social welfare, education and other policies, without necessarily introducing the dimension of constitutional citizenship. Yet to fail to do so is to minimize what is at stake and to miss an opportunity for political education, even mobilization, even if adding concerns for equal citizenship would not necessarily result in a different ruling. Thus even in opinions where courts find other grounds adequate to sustain their decisions, it would be valuable for courts to call attention to the implications of existing policies and practices for gender civic equality more frequently.

Otherwise, the current judicial focus on explicit sex classifications, as in $\underline{\text { U.S. v. }}$ $\underline{\text { Virginia and Nguyen v. INS, }}$ conveys a message to other political actors and the broader public that in relation to gender, achieving civic equality today remains primarily a matter of combating conscious invidious discrimination against women in public laws. Though it undoubtedly remains symbolically valuable to hold such discrimination unacceptable, that message should not, I think, be the predominant one now. Rather the main message should be that in a whole panorama of cases, the Court is confronted with laws, institutions and practices that many, sometimes most, participants in the cases credibly believe to pose major obstacles to women reaching the stature of full citizens, because they deny equal opportunities to aspire, achieve, participate in and contribute to society. Even if the courts do not seek to fix all these problems, they can play a more useful role 
than they are now doing in reminding us that the problems exist, and that they represent failures to realize the most fundamental commitments of our constitutional system.

Michael McCann detailed some of the reasons this role is useful in his important book, Rights at Work (1994), which examined the impact of the ultimately unsuccessful “comparable worth” movement. There he argued convincingly that even though activists seeking pay equity for women won only "limited judicial support” when litigating to achieve their goals, the development of legal discourses defining the harms to be addressed and the existence of cases dramatizing the issues "opened up more than closed debates, exposed more than masked systemic injustices, stirred more than pacified discontents, and nurtured more than retarded the development of solidarity among women workers and their allies” (14). The elaboration of constitutional discourses highlighting the inequities that many existing pay arrangements involved helped mobilize other political actors to pursue change, even when the courts did not embrace most of the specific legal claims being advanced.

In the same way, it is plausible to believe that even if courts felt constrained from invalidating laws or ordering strong remedial measures in many instances, frequent judicial attention to the differential impact of current laws, policies, and practices on gender and citizenship might assist other political actors in defining in compelling ways the problems that need to be addressed. Those actors might then be more able to build political support for change. As many political scientists today are stressing, major constitutional innovations have historically often been brought about by a number of political institutions, agents, and movements who did not rely heavily on litigation or courts (see e.g. Whittington 2001). Precisely because they are so deep and pervasive, the 
transformations needed to promote greater gender civic equality today seem to me ones that need to be addressed through large political movements that affect all the branches of government over time, far more than through judicial decisions. But major changes have often come with constitutional themes playing prominent roles, and courts have played lesser but meaningful parts in bringing those themes to the consciousness of elite governmental actors and the general public.

I do not want to overstate my claims here. Just as I do not think the courts can hand down orders that can radically improve the major structures that stand in the way of gender civic equality today, I also do not think they can enlighten and galvanize other political actors or the public in ways that will play a major role in generating progressive transformations. The impact of judicial decisions that focus less on overt invidious discrimination and more on the differential impacts of laws and policies on constitutional citizenship is likely to remain fairly marginal, whether or not the courts try to order substantial changes themselves. But as stock traders, journal editors, and Florida voters all know, changes in the margins often matter significantly, and they sometimes have momentous consequences. If we cannot hope to move the topic of gender and constitutional citizenship from the margins of contemporary constitutional jurisprudence, we can hope for judicial decisions that embroider those margins in ways that help bring out the best in the rest of the constitutional fabric of American society today.

\section{Bibliography}


Bureau of Labor Statistics. 2006. “American Time Use Survey - 2005 Results Announced by BLS.” At http://www.bls.gov/tus/, accessed November 1, 2006.

Biden, Joseph R. Jr. 1999. “Brief of Senator Joseph R. Biden, Jr. as Amicus Curiae in Support of Petitioners.” At http://supreme.lp.findlaw.com/supreme_court/briefs/99-2999-29fo7/brief/brief01.html, accessed February 18, 2007.

Davis, Martha F., Goldscheid, Julie, Kaufman, Risa E. Wagner, Eileen N., Sunstein, Cass R. 1999. "Brief of Petitioner Christy Brzonkala in United States of America v. Antonio J. Morrison, et al., and Christy Brzonkala v. Antonio J. Morrison, et al.” At http://supreme.lp.findlaw.com/supreme_court/briefs/99-29/99-29mo1a/brief/brief01html, accessed February 18, 2007.

Davis, Peggy Cooper. 2003. “Women, Bondage, and the Reconstructed Constitution.” In Sybil A. Schwarzenbach and Patricia Smith, eds., Women and the United States Constitution: History, Interpretation, and Practice. New York: Columbia University Press, pp. 53-69.

Fineman, Martha Alberton. 2003. “What Place for Family Privacy?” In Sybil A. Schwarzenbach and Patricia Smith, eds., Women and the United States Constitution: History, Interpretation, and Practice. New York: Columbia University Press, pp. 236-254. 
Hirschmann, Nancy J. 2003. The Subject of Liberty: Toward a Feminist Theory of

Freedom. Princeton: Princeton University Press.

Kerber, Linda L. 1998. No Constitutional Right to Be Ladies: Women and the

Obligations of Citizenship. New York: Hill and Wang.

McCann, Michael W. 1994. Rights at Work: Pay Equity and the Politics of Legal

Mobilization. Chicago: University of Chicago Press.

Schneider, Elizabeth M. 2003. “Battered Women, Feminist Lawmaking, Privacy, and

Equality.” In Sybil A. Schwarzenbach and Patricia Smith, eds., Women and the United

States Constitution: History, Interpretation, and Practice. New York: Columbia

University Press, pp.197-220.

Siegel, Reva B. 2006. “You’ve Come a Long Way, Baby: Rehnquist’s New Approach to Pregnancy Discrimination in Hibbs.” Stanford Law Review 58: 1871-1898.

Smith, Rogers M. 2001. “The Distinctive Barriers to Gender Equality.” In Jytte Klausen and Charles S. Maier, eds., Has Liberalism Failed Women? Assuring Equal

Representation in Europe and the United States. New York: Palgrave, pp. 185-199.

Strum, Philippa. 2003. "Women and Citizenship: The Virginia Military Institute Case.”

In Sybil A. Schwarzenbach and Patricia Smith, eds., Women and the United States 
Constitution: History, Interpretation, and Practice. New York: Columbia University Press, pp. 335-346.

Sundberg, Andy. 2007. “Overseas American Demographics: Estimates Based on Data from U.S. Department of State, U.S. Department of Commerce, OECD.”S Study provided to author by American Citizens Abroad. See also "ACA Believes that all U.S. Citizens deserve the same human rights under the laws of the United States, no matter where they live.” At http://www.aca.ch/ppcitiz.htm, accessed February 18, 2007.

Sunstein, Cass R. 1999. One Case at a Time: Judicial Minimalism on the Supreme Court. Cambridge, MA: Harvard University Press.

Tronto, Joan. 2005. “Care as the Work of Citizens: A Modest Proposal.” In Marilyn Friedman, ed. Women and Citizenship. New York: Oxford University Press.

Waxman, Seth P., Ogden, David W., Underwood, Barbara D., McDowell, Barbara, Stern, Mark B., Klein, Alisa B., Murphy, Anne. 1999. “Brief for the United States in United States of America v. Antonio J. Morrison, et al.; Christy Brzonkala v. Antonio J. Morrison, et al.” At http://supreme.lp.findlaw.com/supreme_court/briefs/99-50990005.mer.a..html, accessed February 19, 2007.

Whittington, Keith E. 2001. Constitutional Construction: Divided Powers and Constitutional Meaning. Cambridge, MA: Harvard University Press. 
